DOI https://doi.org/10.18551/rjoas.2016-12.15

\title{
ANALYSIS THE EFFECT OF HUMAN RESOURCES COMPETENCE AND ORGANIZATION OF LEARNING TOWARD PERFORMANCE: STUDIES IN ECONOMICS- BASED COLLEGE IN INDONESA
}

\author{
Fariz* \\ Sekolah Tinggi Ilmu Ekonomi, Yapan Surabaya, Indonesia \\ Setiawan Margono, Irawanto Dodi Wirawan, Sumiati \\ Faculty of Economics and Business, University of Brawijaya, Indonesia \\ *E-mail: fariz@stieyapan.ac.id
}

\begin{abstract}
This research aims to investigate if the competence of human resources affect the organization's performance of Sekolah Tinggi IImu Ekonomi (Economics-based College or STIE), if organizational learning affect organizational performance of STIE, if competence of human resources through innovation culture influence organizational performance of STIE, and if learning organization through organizational competence STIE affect the organization's performance. Descriptive analysis was used to describe and interpret the characteristics of respondents and each of the variables used. Inferential statistical analysis was used to examine the hypothesis. Inferential statistical method that was used to analyze the data of this research was Structural Equation Model (SEM) by using Partial Least Square (PLS). The results of the hypothesis experiment are as follows: that competence of human resources has a positive effect and significant on organizational performance; that organizational learning has a positive effect and significant on organizational performance; that competence of human resources through a culture of innovation has a positive effect and significant on organizational performance; and that learning organization through organizational competence has a positive effect and significant on organizational performance. Based on these results, it indicates that the fourth hypothesis $(\mathrm{H} 4)$ was rejected.
\end{abstract}

\section{KEY WORDS}

Competence HR, organizational learning, innovation culture, performance.

In Indonesia, attempts to improve the quality of the higher education have been done by Dikti through a concept called HELTS (Higher Education Long Term Strategy) 2011-2020. The HELTS concept employs three strategic pillars of the higher education that includes the competing skills, autonomy, and good organization. The improvement of the competing skills is the main focus of this strategy regarding the Human Development Index (HDI) of Indonesia is poor, (www.undp.org/en/statistics) which results from the research done by the Political and Economical Risk Consultancy (PERC) in 2012 showed that the present quality of the education in this country is low.

Other problems related to the higher education in Indonesia is the big number of private-owned universities in Indonesia. Universities are competing each other to get more students since there are too many universities in Indonesia.

The following explanation points out some research gaps related to the studies on the competence of human resources, orientation of learning, working performance and empirical phenomena of higher education which showed various results. The variety of the previous findings were caused by different variables, objects, and indicators. This difference is called research gap as stated by Ferdinand (2006) including;

Firstly, a study on the relationship between the competence of human resources and the performance of the organization in higher education was conducted by Stiles and Kulvisaechana (2004). This research was conducted in Cambridge University which result showed that human capital (intellectual capital, social capital, organizational capital and 
knowledge) had significant influence to the performance of the university. Another research was conducted by Hansson et al., (2004) who conducted the research to 34 universities in Europe (Germany, Spain, France, Swedish, and England). The result of this study showed that the competencies of human resource had significant influence to the performance of the organization including the state-owned universities and private-owned universities as well.

There were some studies showing that the competencies of human resources did not significantly influence the performance of the organization (Chang et al., : 2006) investigated the influence of the human resources' competence, group dynamicity, innovations in the organization and the performance of The Hsinchu Science Park and The Tainian Science Park in Taiwan. The result of this study showed that there was no significant influence of human resources' competencies to the performance of the organizations, However, it was found that the competence of the human resources in relation to the innovations could improve the performance of the organization, which means that innovation is one of the determining point of the organizational performance (Lopez et al., 2005).

Secondly, colleges or universities that conduct organizational learning are the ones that possess skills to create, take, and transfer knowledge by modifying the habit to reflect the knowledge and the new experience. By implementing organizational learning, it is expected that higher education institutions improve their performance (Baldrige national Quality Program, 2010).

Previous studies showed that organizational learning did not always give direct influence to the performance of the organization. Dai et al., (2005), Ismail and Abidin (2008) and Hons et.al., (2010) conducted studies on the relation between organizational learning and organizational performance. The result of those studies support the framework of the excellent education from Baldrige, in which the organizational learning had direct influence to the performance of the organization.

Thirdly, Ulrich (1991) found an insignificant positive influence, while Stranskov (2008) found a positive direct influence. There were gaps on the previous studies related to this issues. Thus, this study is necessary to conduct, especially to investigate the indicators of the performance from the perspective of higher education institutions as the consequences of the skill to compete. Therefore, in this study, the indicators to see the relation between performance and competition skill was adjusted to meet the criteria and the context of the higher education and organizations' indicators of performance with the ones from BAN-PT by adopting and adapting the a concept proposed by Malcolm Baldrige.

Based on the empirical phenomenon and the research gaps, research questions were formulated as follows: Does the human resources competencies influence the organizational performance of the STIE (Sekolah Tinggi IImu Ekonomi or college of Economics)? Does the organizational learning influence the organizational performance of STIE? Do human resources competencies through innovation culture influence the organizational performance of STIE? Does the organizational learning done through organizational competencies influence organizational performance of STIE?

There are some objectives of this study; Analyzing the influence of the human resources competencies to the organizational performance of STIE; Analyzing the influence of the organizational learning to the organizational performance of STIE; Analyzing the influence of the competence of human resources that is improved through innovation culture to the organizational performance of the STIE; Analyzing the influence of organizational learning through organizational competencies to the organizational performance of STIE.

\section{LITERATURE REVIEW}

Theory of Human Resources Competencies. The competencies of human resources that were analyzed in this study were adjusted to fit the context and the object of the higher education institutions which analysis was constructed based on the view proposed by Spencer and Spencer (1993) saying that there were some indicators to see the competencies of the human resources; skills of the leaders, the competence of the lecturers and employees to implement the Tri Dharma Perguruan Tinggi (three pillars of higher 
education) based on their own job and field; knowledge of the related field, personal attributes that show good achievement, dedication, and loyalty of the human resources.

Theory on Organizational Learning. Based on various measurement of organizational learning used by previous researchers, the researcher decided to use the six dimensions of organizational learning as proposed by Senge (1990) and Marquardt (1996) which were; the thinking system which is the conceptual framework used to create clearer pattern in order to allow effective innovation to take place; mental model, which is the ones' assumptions on the influence of the organizational knowledge to life and how to take actions. For instance, how the mental model or learning image of working or studying influence ones' behavior and actions taken during the situations which are related to those variables; Personal skill, indicating ones' capability or high level of skills. This requires ones' continuous effort to keep themselves learning in order to be skillful and to be able to implement the skill to the real organizational work; Team work, which is the skill that focuses on unifying and constructing learning environment that enhances the member's expected excellence; Skills of vision sharing, in which a leader is able to motivate the team member to focus their effort on the same visions to achieve and develop the real working commitment; Dialogue/discussion, the skill to listen, share, and communicate to the team member. This skill requires freedom and creativity to explore issues, listen and strengthen one's view.

Theory of Organizational Competencies. Within the context of higher education, there are mainly three core processes which are the teaching, research and services (Indrajit dan Djokopranoto, 2006). In order to implement the three processes, higher education institutions are required to have adequate competencies which construct strong competitiveness and performance. The competitiveness includes the competence of higher education institutions to respond the global change as the consequences of the competition in the education. The competence of a higher education institution in this study is reflected upon the three pillars of higher education based on the philosophy of the higher education; 1) quality of teaching, 2) quality of research, 3) quality of social service.

Theory of Good University Performance. MBNQA have been frequently implemented in studies conducted by Zink and Vob (2000) in universities in Germany, Baidun (2003) in a manufacture and service company in Palestine, Bombtaia et al., (2003) in colleges in Bahrain, Lau et al., (2003) to manufacture and service company in China, Xiong and Liu (2005) to education institutions and universities in China. The criteria of Malcom Baldrige were built upon basic values and concepts of the integration of basic needs of organization and the working framework that is directed to good result, which include; (1) visionary leadership; (2) learning centered education, (3) organizational and personal learning; (4) valuing employees and partners, (5) agility; (6) focus of the future; (7) managing for innovations.

\section{METHODS OF RESEARCH}

This study implemented the positivism quantitative approach and explanatory research, which is the research that attempted to explain relationship among variables through a series of systematic hypothesis testing (Singarimbun and Effendi, 2006).

The population of this study were the college of economics in Indonesia that provided at least $50 \%$ study programs with B accreditation from BAN-PT. The sample of this study were 11 STIEs. The subjects of this study included the 49 people who were head of the college, head helper I (academic matters), and the head of study programs.

The data collection was done using questionnaires consisting of several written question which the respondents had to answer by providing information related to the identity (name, age, job, position, and the working experience as leaders in the university) and giving opinion, views to the given question related to the indicators and variables of the study toward the objective empirical situations or reality in the STIEs

Inferential statistical analysis was employed to test the predetermined hypothesis. The inferential statistical method that was used to analyze the data of this study was the 
Structural Equation Model (SEM) using the Partial least Square (PLS). PLS is an alternative approach of SEM approach from the covariant to variant (Ghozali, 2005 dan Solimun, 2010).

\section{RESULTS OF RESEARCH}

The result of the t-statistic test was used to answer the hypothesis of this study as shown in Table 1.

Table 1 - Table of Direct Influential Test

\begin{tabular}{|l|l|l|l|}
\hline \multicolumn{1}{|c|}{ Path } & Original sample & t statistic & \multicolumn{1}{|c|}{ Notes } \\
\hline Competencies of HR $\left(\mathrm{X}_{1}\right) \rightarrow$ Organizational performance $(\mathrm{Y})$ & 0,6492 & 3,3744 & Significant \\
\hline Organizational learning $\left(\mathrm{X}_{2}\right) \rightarrow$ Organizational performance $(\mathrm{Y})$ & 0,5923 & 2,9686 & Significant \\
\hline Competencies of $\mathrm{HR}\left(\mathrm{X}_{1}\right) \rightarrow$ Culture of Innovation $\left(\mathrm{X}_{3}\right)$ & 0,5113 & 2,691 & Significant \\
\hline Culture of Innovation $\left(\mathrm{X}_{3}\right) \rightarrow$ Organizational performance $(\mathrm{Y})$ & 0,4712 & 2,2998 & Significant \\
\hline Organizational learning $\left(\mathrm{X}_{2}\right) \rightarrow$ Organizational competencies $\left(\mathrm{X}_{4}\right)$ & 0,3214 & 1,8686 & Not Significant \\
\hline Organizational competencies $\left(\mathrm{X}_{4}\right) \rightarrow$ Organizational performance $(\mathrm{Y})$ & 0,4872 & 2,4798 & Significant \\
\hline
\end{tabular}

Based on Table 1, it can be explained that the result of the test showed the $t$ value of the competencies of human resources $\left(\mathrm{X}_{1}\right) \rightarrow$ organizational performance $(\mathrm{Y})$ was at 3.3744 . Since the value was $>1.96$, thus the competencies of the human resources have significant influence to the performance of the organization as much as 0.6492 .

The $t$ value of the organizational learning $\left(X_{2}\right) \rightarrow$ organizational performance $(Y)$ was at 2.9686. Since the value was $>1.96$, thus the organizational learning influenced the performance of the organization as much as 0.5923 .

The $t$ value of the competencies of human resources $\left(X_{1}\right) \rightarrow$ culture of innovation $\left(X_{3}\right)$ was at 2.961. Since the value was $>1.96$, thus the competencies of the human resources had significant influence to the culture of innovations as much as 0.5113

The $t$ value of the culture of innovation $\left(\mathrm{X}_{3}\right) \rightarrow$ organizational performance $(\mathrm{Y})$ was at 2.2998. Since the value was $>1.96$, thus the culture of innovation influenced the performance of the organization as much as 0.4712 .

The t value of the organizational learning $\left(X_{2}\right) \rightarrow$ organizational competencies $\left(X_{4}\right)$ was at 1.868. Since the value was $>1.96$, thus the organizational competencies did not influence the organizational competencies.

The $t$ value of the organizational competencies $\left(\mathrm{X}_{4}\right) \rightarrow$ organizational performance $(\mathrm{Y})$ was at 2.4798. Since the value was $>1.96$, thus the organizational competencies influenced the performance of the organization as much as 0.4872 .

Two kinds of indirect influence test was adminiestered in two steps; (1) the influence of the human resources competencies to the organizational performance through the culture of innovations; (2) the influence of the organizational learning to the organizational performance through organizational competencies. The result of the test is shown in Figure 1.

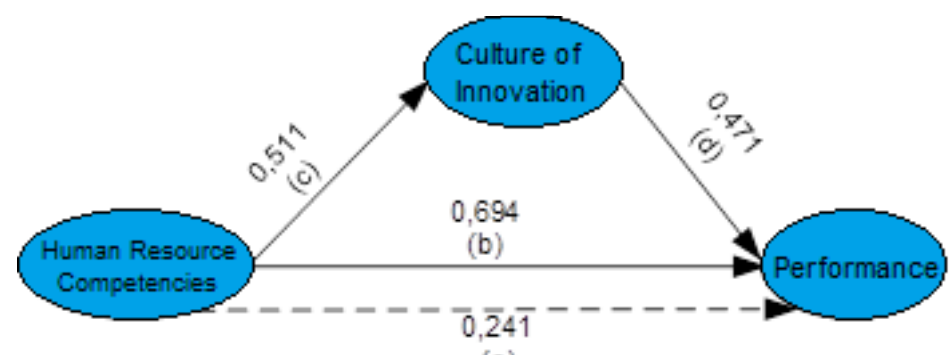

(a)

Figure 1 - Indirect Influence of Human Resources Competencies to the Organizational Performance through the Culture of Innovation

The competencies of the human resources had significant influence to the culture of innovation as much as 0.511 . The culture of innovation had a significant influence to the 
organizational performance at 0.471 . The human resources competencies significant influenced the organizational performance at 0.694. Meanwhile, the human resouces competencies had indirect influnce to the organizatioal performance through culture of innovation at 0.241 .

To test the level of intervention of mediator variable to find out if it is full mediation, partial mediation, or no mediation. The method to test the mediator variable was adapted from (Hari et al, 2010); to test the indirect influence of the human resources competencies to the organizational performance in this study required the use of mediator variable (culture of innovation). The result of the test showed that there was a significant indirect influence as much as 0.241 .

To test the influence of the independent variable (the competencies of the human resources) to the dependent variable (organizational performance) in the model did not require the use of mediator variable. The influence of the human resources competencies to the culture of innovation was at 0.11 which meant significant. The test on the influence of the mediator variable (culture of innovation) to the dependent variable (organizational performance) showed significant value of 0.471 .

Based on the result of investigation on those four influential factors (a, b, c, d), it can be concluded that the culture of education was the mediator variable since the (c), (d) and (a) were significant, while the (a) was lower than (b) that can be determined as the mediator partial mediation.

Hasil PLS pengaruh tidak langsung pengaruh pembelajaran organisasi terhadap kinerja organisasi melalui kompetensi organisasi dapat dilihat pada Gambar 2.

The result of the PLS on the indirect influence of the organizatioanl leraning to the organizatioal performance through organizational competencies can be seen in Figure 2.

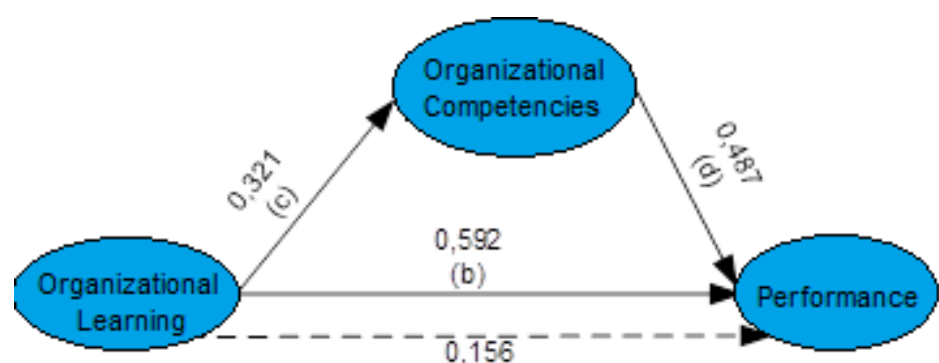

(a)

Figure 2 - Indirect influence of Organizational Learning to the Organizational Performance through Organizational Competencies

The organizational learning did not influence the organizational competence at 0.511 . The organizatioanl competencies significantly inflienced the organizational performance as much as 0.487. Whilst, the organizational learning had significant influence to the performance at 0.592. Meanwhile, the organizational learning had indirect influence to the performance through organizational competencies at 0.156.

A test was administered to see the indirect influence of the organizational leraning to the organizational performance, mediator variable was included in the pattern. The test showed that there was an indirect influence of 0.156 with significant result.

A test on the influence of the independent variable (organizational leraning) to the independent variable (organizational performance) without using mediator variable in the pattern showed that there was an influence of 0.592 with significant result.

A test on the influence of the independent variable (organizational learning) to the mediator variable (organizational competencies) showed that the organizational leraning had influence on the organizational competencies at 0.321 with insignificant result.

A test on the influence of the imediator variable (organizational competencies) to the dependent variable (organizational performance) showed that there was an influence as much as 0.487 with significant result. 
Based on the result of the investigation on the four variables, it is concluded that the mediator variable (organizational competencies) was not the mediator variable since the organizational learning did not have significant influence to it.

\section{DISCUSSION OF RESULTS}

The result of the analysis on the influence of human resources competencies to the organizational performance showed a positive and significant relationship. The result implied that the higher the competencies of the human resources, the better the organizational performance of the institution. Based on the analysis on the pattern, the human resources competencies were reflected upon personal attributes. Personal attributes were able to distinguish ones who have good performance such as achievement, dedication and loyalty from those who do not have them. By making investment on the human resources, institution is also improving the organizational performance as wqell.

The influence of organizatioal learning to the organizational performance implied that it is crucial for institutions to create good learning atmosphere since organizational learning has been proven to play a positive and significant influence to the organizational performance. Therefore, the better the quality of organizational learning, the better the organizational performance.

The result of the data analysis also showed that through the culture of innovation, human resources competencies has positive and significant influence to the organizational performance of the college (STIE). It implied that the human resources competencies improves the culture of innovation which means that the better the culture of innovation, the better the organizational performance. Innovations can be implemented by improving the quality of the study program, the practice of teaching and learning and the implementation of excellent services.

This study resulted to a conclusion that the organizational learning done through organizational competencies does not influence the organizational performance. Organizational competencies were not eh mediator variable which means that the organizational learning influences the organizational performance without going through other variable. This result is different from the result of the research done by Zong Dai et al (2005) whose research was conducted at Anysis University and results showed that the organizational learning improved the organizational competencies which would improve the organizational performance. Kasim (2010) also found a different result showing that improvement to the human resources through organizational learning also improved the organizational competencies and organizational performance as well.

The result of this study is expected to contribute as a guidance for the leaders and managers of STIEs in East Java . It is important that leaders concern about the importance of innovations to the betterment of the organizational performance. The culture of innovation was found to be the mediator between the human resources competencies to improve the organizational performance.

STIEs have made attempts to improve the comptencies of the human resources by improving the number of the lecturers who are continuing their studies to higher degrees to be given higher academic-related functional position regarding to the fact that the human resources competencies have positive and significant influence to the STIEs' organizational performance.

It is also important that the STIE leaders conduct organizational learning that enhances personal skills. The personal skills can be seen from the change of attitudes and positive manners, being responsible, and the skill to adapt well to any situation. Those positive attitudes improve the organizational performance since the organizational learning also play a positive and significant influence to the organizational performance of the STIEs.

The leaders of the STIEs also need to be able to utilize the human resources to always create innovations. Contiunous innvovation should be facilitated consistently to achieve the vision of the orgnaizaition that also improve the organizational performance at the same time. Innovations can be done to improve the quality of the study program, teaching and learning 
activities as well as services. Leaders of STIE are also required to give more considerations to the varialbes that improve the organizational performance such as human resources competencies and organizational learning.

\section{CONCLUSIONS}

Based on the result of the PLS testing on the direct and indirect influence of the variables, the hypotesis testing is described as follows:

Hypothesis one, the competencies of the human resources have positive and significant influence to the organizational performance of STIE. The Table 1 shows that the $t$ value of the test on the competencies of human resources $\left(X_{1}\right) \rightarrow$ organizational performance $(Y)$ is 3.3744. Since the $t$ value $>1,96$, it can be conclued that the human resources competencies afftect the organizational performance. Therefore, the hypotesis one $(\mathrm{H} 1)$ is accepted.

Hypothesis two, the organizational learning has positive and significant influence to the organizational performance of STIE. The Table 5.25 shows that the $t$ value of the test on the organizational learning $\left(X_{2}\right) \rightarrow$ organizational performance $(Y)$ is 2.968 . Since the t value $>1$, 96 , it can be conclued that the organizational learning afftects organizational performance. Therefore, the hypotesis two $(\mathrm{H} 2)$ is accepted.

Hypothesis three, the competencies of the human resources through the culture of innovations have positive and significant influence to the organizational performance of STIE. The result of the test on indrect influence shown in Figure 5.8 shows that the t value of the test on the competencies of human resources through the culture of innovation have positive and significant influence to the organizational performance in which the culture of innovation functions as the partial medational variable. Therefore, the hypotesis three $(\mathrm{H} 3)$ is accepted.

Hypothesis four, the organizational learning through the organizational comptencies has a positive and significant influece toward the organizational performance of STIE. The result of the test on indirect influence shown in Figure 5.9 shows that the organizational learning through the organizational competencies does not influence the organizational performance. The organizational competencies do not function as mediator variable. Therefore, the hypotesis four $(\mathrm{H} 4)$ is rejected.

\section{REFERENCES}

1. Baldrige National Program. (2005). Evaluation of the Baldrige Quality Program, NIST Planning Report, October 3th

2. Baldrige Performance Excellence Program. (2011). 2011-2012 Education Criteria for Performance Excellence. National Institute of Standards and Technology, Department of Commerce.

3. Chang, S.C., Chiang, C.Y., Chu, C.Y and Wang, Y.B. (2006). The Study of Social Capital, Organizational Learning, Innovativeness, Intellectual Capital and Performance. The Journal of Human Resource and Adult Learning, November 2006

4. Dai, Z., Duserick, F., and Dai, L. (2005). Achieving Competitiveness by Organizational Learning: Strategy, Transformation and Measurement ini Anisys University. Issues in Information Systems, Volume VI, No.2

5. Hansson, B., Johanson, U., and Leitner, K.H. (2004). The Impact of Human Capital and Human Capital Investments of Company Performance, Office for Official Publications of the European Communities.

6. Hons, C., Xie, H., Wang, C., \& Liu, C. (2008). Organizational Learning, Knowledge Energy, Core Competency and Firm Performance. Science of Science and Management of $S \& T$

7. Lopez, S.P., Peon, J.M.M., \& Ordas, C.J.V. (2005). Human Resource Practices, Organizational Learning and Business Performance. Human Resource Development International, 8(2). 
8. Marquardt, M.J. (1996). Building the Learning Organization, New York: McGrw Hill Companies, Inc

9. Senge, P.M. (1990). The Leader's New York: Building Learning Organizations. Sloan Management Review, Fall 32 (1), pp.7-23

10. Stile, P. \& Kulvisaechana, S. (2002). On The Link Between Human Capital and Firm Performance, FEP Work Paper, No.121 November 2002

11. Strandskov, J. (2006). Sources of Competitive Advantages and Business Performance. Journal of Business Economics and Management, 7(3), 119-129

12. Ulrich. (1991). Organizational Capability: Creating Competitive Advantage. Academy of Managemet Executive 5(1): 77-92 